Peakall, R. and P. E. Smouse (2006): Genalex 6: genetic analysis in Excel. Population genetic software for teaching and research. Mol. Ecol. Notes 6: 288-295.

Posnette, A. F. and J. M. A. TodD (1951): Virus diseases of cacao in West Africa. VIII. The search for virus resistant cacao. Annals of Applied Biology 38: 785-800.

Powell, W., M. Morgante, C. Andre, M. Hanatey, J. Vogel, S. TingeY and A. RAFALSKI (1996): The comparison of RFLP, RAPD, AFLP and SSR (microsatellite) markers for germplasm analysis. Molecular Breeding 2: 225-238.

Pritchard, J. K., M. Stephens and P. Donnelly (2000): Inference of population structure from multilocus genotype data. Genetics 155: 945-959.

Pugh, T., O. Fouet, A. M. Risterucci, P. Brottier, M. Abouladze, C. Deletrez, B. Courtois, D. Clement, P. LARMANDE, J. A. K. NGoran and C. Lanaud (2004): A new cacao linkage map based on codominant markers: development and integration of 201 new microsatellite markers Theor. Appl Genet 108: 1151-1161.

Purseglove, J.W. (1974): Tropical crops, dicotyledons. John Wiley \& Sons, New York.

Quenollle, M. (1956): Notes on bias in estimation. Biometrika 43: 253-260.

Rice, W. R. (1989): Analyzing tables of statistical tests. Evolution 43: 223-225.

Rice, R. A. and R. Greenberg (2000): Cacao cultivation and the conservation of biological diversity. Ambio 29(3): 167-173.

Saunders, J. A., S. MischKe, E. A. Leamy and A. A. HEMEIDA (2004): Selection of international molecular standard for DNA fingerprinting. Theor. Appl. Genet. 110: 41-47.

Schnell, R. J., C. T. Olano, J. S. Brown, A. W. Meerow, C. Cervantes-Martinez, C. Nagai and J.-C. Motamayor (2005): Retrospective determination of the parental population of superior cacao (Theobroma cacao L.) seedlings and association of microsatellite alleles with productivity. J. Amer. Soc. Hort. Sci. 130: 181-190.

Sereno, M., P. P. Albuquerque, R. Vencovsky and A. FIGUERA (2006): Genetic diversity and natural population structure of cacao, Theobroma cacao L. from the Brazilian Amazon evaluated by microsatellite markers. Conservation Genetics 7: 13-24.

Sweigart, A., K. Karoly, A. Jones and J. H. Willis (1999): The distribution of individual inbreeding coefficients and an pairwise relatedness in a population of Mimulus guttatus. Heredity 83: 625-632.

Toxopeus, H. (1964): $\mathrm{F}_{3}$ Amazon cacao in Nigeria. Rep. Cacao Res. Inst. Nigeria, 1963/64, pp.13-22.

WeIR, B. S. and C. C. CoCKERHAM (1984): Estimating F-statistics for the analysis of population structure. Evolution 38: 1358-1370.

WRIGHT, S. (1965): The interpretation of genetic structure by F-statistics with special regard to systems of mating. Evolution 19: 355.

Zhang, D., E. Arevalo, B. Mischke, L. Zuniga and A. BarRETO (2006a): Genetic diversity and population structure of cocoa, Theobroma cacao L. in the Hullaga and Ucayali valleys of Peru. Annals of Botany 98: 647-655.

Zhang, D., E. Arevalo, S. Mischke, R. Goenaga, A. A. HEMEIDA and J. A. SAUNDERS (2006b): Accuracy and reliability of high-throughput microsatellite genotyping for cacao clone identification. Crop Science 46: 2084-2092.

Zhang, D., M. Boccara, L. Motilal, D. R. Butler, P. Umaharan, S. Mischke and L. Meinhardt (2008): Microsatellite variation and population structure in the "refractario" cacao of Equador. Conserv Genet 9: 327-337.

Zhang, D., S. Mischke, E. S. Johnson, W. Phillips-Mora and L. Meinhardt (2009): Molecular characterization of an International cocoa collection using microsatellite markers. Tree Genetics \& Genomes 5: 1-10.

\title{
Cross-amplification and Characterization of Polymorphic Microsatellite Markers From Acacia (Senegalia) mellifera and Acacia brevispica to Acacia senegal (L.) Willd.
}

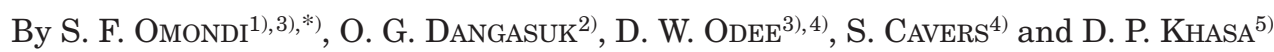

(Received $6^{\text {th }}$ May 2009)

\footnotetext{
1) Department of Forestry and Wood Science, Moi University, P.O Box 1125 Eldoret, Kenya.

2) Department of Biological sciences, Moi University, P.O. Box 1125 Eldoret, Kenya.

${ }^{3}$ ) Kenya Forestry Research Institute, P.O. Box 20412-00200 Nairobi, Kenya

4) Centre for Ecology and Hydrology, Bush Estate, Penicuik, Midlothian, EH26 0QB, UK.

5) Centre for Forest Research and Canada Research Chair in Forest and Environmental Genomics, Université Laval, SainteFoy, Québec, Canada G1V 0A6.

*) Author of correspondence: STEPHEN F. OMONDI. E-Mail: stephenf.omondi@gmail.com
}

\begin{abstract}
Seven polymorphic microsatellite markers isolated from Acacia brevispica and Acacia mellifera were successfully cross-amplified in Acacia senegal. The loci were surveyed for polymorphism using 30 samples. Allelic diversity ranged from 4 (Ame02, $A b 06$ and Ab18) to 13 (Ab26) per locus. The expected heterozygosity $\left(\mathrm{H}_{\mathrm{F}}\right)$ ranged from 0.543 (Ame02) to 0.868 (Ab26) while observed heterozygosity $\left(\mathrm{H}_{\mathrm{O}}\right)$ ranged from 0.516 (Ame05) to 0.800 (Ame03). Cross-amplification of these loci represents a potential source of co-dominant markers and will be useful in the study of genetic diversity, structure,
\end{abstract}


gene flow and breeding systems of this important Acacia species.

Key words: Acacia senegal, cross-amplification, genetic diversity, microsatellite, Sub-Saharan Africa.

\section{Introduction}

Acacia senegal (L.) Willd. is a multipurpose agroforestry tree, native to the arid and semi-arid lands of Sub-Saharan Africa but found as far as the Indian subcontinent. It grows to a height of 5-12 m, with a trunk up to $30 \mathrm{~cm}$ in diameter (FAGG and ALLISON, 2004) and is valued for gum arabic production, as well as secondary agricultural roles, such as restoring soil fertility and providing fuel and fodder (BALLAL et al., 2005). It is also essential in sand dune fixation and is preferred in bushfallow rotation and intercropping (ANDERSON and WEIPING, 1992). The species has four varieties: senegal, kerensis, rostrata and leiorhachis but their delimitation is still problematic (FAGG and ALLISON, 2004). Intraspecific variation has been reported in morphological, molecular and biochemical characteristics (CHIKAMAI and Odera, 2002; Motlagh et al., 2006; Al-Assaf et al., 2007). Despite its ecological and economic importance, little progress has been made in developing sets of molecular markers for genetic studies.

Table S1. - Microsatellite loci isolated for A. brevispica (SCHNABEL et al., 2005) and A. mellifera (RUIZ-GUAJARDO et al., 2007) used in cross-amplification study in A. senegal.

\begin{tabular}{|c|c|c|}
\hline Locus Accession no. & Microsatellite repeat & Loci amplification \\
\hline$A b 01$ & $(\mathrm{AAG})_{15}$ & Irregular amplification \\
\hline$A b 02$ & $(\mathrm{AC})_{11}$ & Poor amplification \\
\hline$A b 03$ & $(\mathrm{AC})_{17}$ & No amplification \\
\hline$A b 04$ & $(\mathrm{AC})_{7}$ & No amplification \\
\hline$A b 05$ & $(\mathrm{AG})_{8} \ldots$ & No amplification \\
\hline$A b 06$ & $(\mathrm{AC})_{9}(\mathrm{AG})_{10}$ & Polymorphic amplification \\
\hline$A b 07$ & $(\mathrm{ATC})_{7}$ & Irregular amplification \\
\hline$A b 09$ & $(\mathrm{AAAC})_{6}$ & No amplification \\
\hline$A b 10$ & $(A G)_{13}$ & No amplification \\
\hline$A b 12$ & $(\mathrm{AG})_{11}$ & Irregular amplification \\
\hline$A b 13$ & $(\mathrm{AG})_{19}$ & No amplification \\
\hline$A b 14$ & $(\mathrm{AG})_{10}$ & Irregular amplification \\
\hline$A b 15$ & $(\mathrm{AC})_{10}$ & Poor amplification \\
\hline$A b 16$ & $(\mathrm{AT})_{8}(\mathrm{AG})_{11}$ & Irregular amplification \\
\hline$A b 17$ & $(\mathrm{AAG})_{14}(\mathrm{ATC})_{11}$ & Poor amplification \\
\hline$A b 18$ & $(\mathrm{AAG})_{15}$ & Polymorphic amplification \\
\hline$A b 19$ & $(\mathrm{AC})_{16}$ & No amplification \\
\hline$A b 20$ & $(\mathrm{AG})_{24}(\mathrm{AC})_{16}$ & No amplification \\
\hline$A b 21$ & $(\mathrm{AGAT})_{23}$ & No amplification \\
\hline$A b 22$ & $(\mathrm{AG})_{11}$ & Poor amplification \\
\hline$A b 23$ & $(\mathrm{AC})_{9}(\mathrm{AC})_{7}$ & No amplification \\
\hline$A b 25$ & $(\mathrm{AC})_{7}$ & Poor amplification \\
\hline$A b 26$ & $(\mathrm{AG})_{8}(\mathrm{AG})_{9}$ & Polymorphic amplification \\
\hline$A b 27$ & $(\mathrm{AC})_{7}$ & No amplification \\
\hline Ame01 & $(\mathrm{AAG})_{7}$ & No amplification \\
\hline Ame02 & $(\mathrm{AC})_{7}(\mathrm{AG})_{11}$ & Polymorphic amplification \\
\hline Ame03 & $(\mathrm{AG})_{9}$ & Polymorphic amplification \\
\hline Ame04 & $(A G)_{10}$ & Poor amplification \\
\hline Ame05 & $(\mathrm{ATC})_{7}$ & Polymorphic amplification \\
\hline Ame06 & $(\mathrm{GT})_{10}$ & Poor amplification \\
\hline Ame07 & $(\mathrm{GT})_{20}$ & Polymorphic amplification \\
\hline Ame08 & $(\mathrm{GTT})_{9}$ & No amplification \\
\hline Ame09 & $(\mathrm{GA})_{17}$ & No amplification \\
\hline Ame10 & $(\mathrm{CA})_{9}$ & No amplification \\
\hline Ame12 & $(\mathrm{CT})_{12}(\mathrm{AC})_{6}$ & No amplification \\
\hline
\end{tabular}

S1- Supplementary material (Table 1). 
Table 1. - Microsatellite loci in A. senegal obtained from cross amplification from A. mellifera and A. brevispica including GenBank accession number; $\mathrm{Ta}$ - annealing temperature (touchdown range); $\mathrm{bp}$ - expected allelic size in base pairs; $\mathrm{A}$ - number of alleles


gosity; $\mathrm{y}, \mathrm{H}_{\mathrm{O}}$ recorded for the original species; $\mathrm{H}_{\mathrm{E}}$ - expected heterozygosity; $\mathrm{z}, \mathrm{H}_{\mathrm{E}}$ recorded for the original species.

\begin{tabular}{|c|c|c|c|c|c|c|c|}
\hline Accession no. & Primer sequence & Repeat motif & $\mathrm{Ta}\left({ }^{\circ} \mathrm{C}\right)$ & Size (bp) & $\mathrm{A}(\mathrm{n})\{\mathrm{x}\}$ & $\mathrm{H}_{\mathrm{O}}\{\mathrm{y}\}$ & $\mathrm{H}_{\mathrm{E}}\{\mathrm{z}\}$ \\
\hline Ame02 & F-GAACCATCAGCGTAATAA & \multirow{2}{*}{$(\mathrm{AC})_{7}(\mathrm{AG})_{11}$} & \multirow{2}{*}{$55-45$} & \multirow{2}{*}{117} & \multirow{2}{*}{$4(30)\{7\}$} & \multirow{2}{*}{$0.670\{0.792\}$} & \multirow{2}{*}{$0.543\{0.802\}$} \\
\hline$D Q 467674$ & R-GGTTTAGCAACATACTATCTC & & & & & & \\
\hline Ame03 & F-GAACAATATCAGCAATCACT & \multirow{2}{*}{$(\mathrm{AG})_{9}$} & \multirow{2}{*}{$55-45$} & \multirow{2}{*}{139} & \multirow{2}{*}{$8(30)\{4\}$} & \multirow{2}{*}{$0.800\{0.271\}$} & \multirow{2}{*}{$0.810\{0.339\}$} \\
\hline$D Q 467673$ & R-CCTCATGCACACACAAGAT & & & & & & \\
\hline Ame05 & F-CCCAACAAAGATCATCAT & \multirow{2}{*}{$(\mathrm{ATC})_{7}$} & \multirow{2}{*}{$58-48$} & \multirow{2}{*}{203} & \multirow{2}{*}{$5(30)\{13\}$} & \multirow{2}{*}{$0.516\{0.532\}$} & \multirow{2}{*}{$0.530\{0.580\}$} \\
\hline$D Q 467656$ & R-ATGGTTCAGTTTCTTTATTCT & & & & & & \\
\hline$D Q 467658$ & R-GTCCAAAACTCTTCAATGTCAA & $(\mathrm{GT})_{20}$ & $55-45$ & 353 & $10(30)\{19\}$ & $0.695\{0.958\}$ & $0.802\{0.911\}$ \\
\hline$A b 06$ & F-CCTTCTTTGACGGTATTC & \multirow{2}{*}{$(\mathrm{AC})_{9}(\mathrm{AG})_{10}$} & \multirow{2}{*}{$58-48$} & \multirow{2}{*}{147} & \multirow{2}{*}{$4(30)\{7\}$} & \multirow{2}{*}{$0.785\{1.00\}$} & \multirow{2}{*}{$0.745\{0.911\}$} \\
\hline AY843537 & R-TCATCTCTCTTCTCCATT & & & & & & \\
\hline$A b 18$ & F-GAAGGGTCTGGCATTAC & \multirow{2}{*}{$(\mathrm{AAG})_{15}$} & \multirow{2}{*}{$60-50$} & \multirow{2}{*}{212} & \multirow{2}{*}{$4(30)\{3\}$} & \multirow{2}{*}{$0.717\{0.312\}$} & \multirow{2}{*}{$0.579\{0.280\}$} \\
\hline AY843549 & R-CGACGACGAAGATACT & & & & & & \\
\hline$A b 26$ & F-ATATTCTGCTTTAGTCTA & $(\mathrm{AG})_{8}(\mathrm{AG})_{9}$ & $61-51$ & 126 & $13(30) 563$ & 0780506871 & 0868407521 \\
\hline
\end{tabular}

" All the forward primers were tagged with M13R tag 5'-CACGACGTTGTAAAACGAC-3'.

Microsatellites are among the best classes of markers for studying genetic processes in natural populations because they are abundant, co-dominant, interspersed throughout the genome, possess high resolution power and polymorphism (CHASE et al., 1996). Their development, however, requires a significant investment (FERNANDEZ et al., 2000); therefore, when markers have been developed in taxonomically related species, it is worthwhile testing for cross-amplification. In this brief preliminary study thirty-four microsatellite primers developed from A. mellifera and A. brevispica were tested for cross-amplification in $A$. senegal.

\section{Materials and Methods}

Microsatellite loci screening

Genomic DNA was isolated from leaves following a modified CTAB procedure (FERNANDEZ et al., 2000). Thirty four microsatellite loci isolated from Acacia mellifera (RUIZ-GUAJARDO et al., 2007) and Acacia brevispica (SCHNABEL et al., 2005) were tested for amplification in 4 A. senegal DNA samples. PCR runs containing $20 \mathrm{ng}$ of DNA, 1x PCR buffer (10 mM Tris-HCL ( $\mathrm{pH} 8.3$ ), $50 \mathrm{mM}$ $\mathrm{KCl}$ ), $2.5 \mathrm{mM} \mathrm{MgCl}_{2}, 200 \mu \mathrm{M}$ of each dNTP, $0.1 \mu \mathrm{M}$ of each primer, and 1 unit of Taq DNA polymerase (Invitrogen), were performed in a volume of $10 \mu \mathrm{l}$ (RUIZ-GUAJARDO et al., 2007, OTERO-ARNAIZ et al., 2005). Reactions were carried out on an MJ Research thermal cycler following a touchdown protocol: $95^{\circ} \mathrm{C}$ for 3 minutes; 20 cycles of $95^{\circ} \mathrm{C}$ for 30 seconds, either $60^{\circ} \mathrm{C}-50^{\circ} \mathrm{C}$, $58^{\circ} \mathrm{C}-48^{\circ} \mathrm{C}$ or $55^{\circ} \mathrm{C}-45^{\circ} \mathrm{C}\left(-0.5^{\circ} \mathrm{C}\right)$ for 30 seconds, $72^{\circ} \mathrm{C}$ for 30 seconds; 10 cycles of $95^{\circ} \mathrm{C}$ for 30 seconds, $50^{\circ} \mathrm{C}$, $48^{\circ} \mathrm{C}$ or $45^{\circ} \mathrm{C}$ for 30 seconds, $72^{\circ} \mathrm{C}$ for 30 seconds; final extension of $72^{\circ} \mathrm{C}$ for 10 minutes and held at $4^{\circ} \mathrm{C}$. PCR products were electrophoresed alongside $100 \mathrm{bp}$ ladder, stained in ethidium bromide and visualized under UVlight. Loci that produced single, distinct bands at the expected size were selected for further screening.
Forward primers of the selected loci were tagged with $\mathrm{M}_{13}$ fluorescent tail and optimized using different annealing temperatures, PCR buffers, $\mathrm{Mg}^{2+}$, dNTPs, primer and Taq DNApolymerase concentrations. The mix that produced sharpest and most distinct bands at the expected size was selected (20 ng of genomic DNA, $1 \mathrm{X}$ PCR buffer (10 mM Tris- $\mathrm{HCl} \mathrm{pH} 8.3,50 \mathrm{mM} \mathrm{KCl}$ ), $1.5 \mathrm{mM} \mathrm{MgCl}_{2}, 200 \mu \mathrm{M}$ of each dNTP, $0.05 \mu \mathrm{M}$ of each primer, and 1 unit of Taq DNA polymerase). These loci were then tested for polymorphism and reproducibility.

\section{Polymorphism testing}

The final set of loci was screened for polymorphism using a set of 30 DNA samples (3 samples per population from 10 populations). PCR was carried out as described above and products separated on $0.25 \mathrm{~mm}$ denaturing polyacrylamide gels containing $10 \%$ Ammonium Persulfate (APS), tetramethylethylenediamine (TEMED)Omnipur and 8\% acrylamide (Gene-PAGE plus)Amresco and electrophoresed using $1 \mathrm{X}$ TBE buffer on a Li-Cor IR 4200 DNA sequencer. Band sizes were determined by referencing standard IRD800, 50-350 bp and 50-700 bp ladder (KHASA et al., 2005). Loci that were polymorphic and informative were then selected as a set of $A$. senegal markers for further studies.

\section{Results}

Out of the 34 loci screened, 11 were selected for polymorphism screening with a larger number of DNA samples while others failed to amplify or showed poor amplification (Table S1). During the screening, 7 loci (Table 1) showed positive amplification and unambiguous patterns of polymorphic bands and were selected as $A$. senegal markers. The loci showed features desired for œdominant molecular markers in the species. No deviation from Hardy Weinberg equilibrium or linkage dise- 
quilibrium was detected between loci $(\mathrm{P}>0.05)$ (RAYMOND and Rousset, 1995). The number of alleles and expected heterozygosity were also estimated for each locus. The total number of alleles was highly variable across loci, ranging from 4 (Ame02, Ab06 and Ab18) to 13 (Ab26) (Table 1). Expected heterozygosity ranged from 0.543 (Ame02) to 0.868 (Ab26) (Table 1). Overall, the loci proved to be informative, at levels comparable to the source species and microsatellite loci of other tropical tree species.

\section{Conclusion}

This study unveiled evidence that cross-transferability of developed microsatellite loci can increase the availability of markers to address both ecological and evolutionary questions in A. senegal. These loci will form a useful marker set for population genetic studies of the species. These will include detecting and understanding available genetic diversity within the species range for maximum utilization and conservation purposes.

\section{Acknowledgements}

This work was funded by Department of Foreign Affairs and International Trade Canada (DFAIT) through Canadian Bureau for International Education (CBIE) in the framework of Graduate Student Exchange program (GSEP) grant for 2007 and Kenya Forestry Research Institute (KEFRI), through ACACIAGUM project. We thank Mr. JoHN GICHERU of KERFI and ANDRÉ GAGNÉ of Center for Forest Research, Université Laval for coordinating the acquisition of research materials and all colleagues at the bioinformatics Centre for their advice and support.

\section{References}

Al-Assaf, S., G. O. Phillips, H. Aoki and Y. SASAKI (2007): Characterization and properties of Acacia senegal (L.) Willd. var. senegal with enhanced properties (Acacia (sen) SUPER GUM ${ }^{\mathrm{TM}}$ ): Part 1. Controlled maturation of Acacia senegal var. senegal to increase viscoelasticity, produce a hydrogel form and convert a poor into a good emulsifier. Food Hydrocolloids 21: 319-328.
Anderson, D. M. W. and P. W. Weiping (1992): Gum arabic (Acacia senegal) from Uganda: characteristics NMR spectra, amino compositions and gum/soil cationic relationships. International Tree Crops Journal 7: (3), 167-179.

Ballal, M. E., E. A. El-Siddig, M. A. Elfadl and O. LUUKKANEN (2005): Relationship between environmental factors, tapping dates, tapping intensity and gum arabic yield of an Acacia senegal plantation in western Sudan. Journal of Arid Environments 63 379-389.

Chase, M., R. Kesseli and K. Bawa (1996): Microsatellite markers for population and conservation genetics of tropical trees. American Journal of Botany 83: (1), 51-57.

Chikamai, B. N. and J. A. Odera (2002): Commercial plant gums and resins in Kenya. Nairobi, Kenya.

FAGG, C. W. and G. E. Allison (2004): Acacia senegal and Gum Arabic Trade. Oxford Forestry Institute, Tropical Forestry Papers. No. 42.

Fernández, J. F., V. L. Sork, G. Gallego, J. López, A. Bohorques and J. ToHme (2000): Cross-Amplification of microsatellite loci in a Neotropical Quercus Species and standardization of DNA extraction from mature leaves Dried in silica gel. Plant Molecular Biology Reporter 18: 397-397.

Khasa, P. D., P. Pollefeys, A. Navarro-Quezada, P. Perinet and J. Bousquet (2005): Species-specific Microsatellite markers to monitor gene flow between exotic poplars and their natural relatives in eastern North America. Molecular Ecology Notes 5: 920-923.

Motlagh, S., P. Ravines, K. A. KaRAmallah and M. QIFENG (2006): The analysis of Acacia gums using electrophoresis. Food Hydrocolloids 20: (6), 848-854.

RAYMOND, M. and F. RousseT (1995): GENEPOP Version 1.2: population genetics software for exact tests and ecumenicism. Journal of Heredity 86: 248-249.

Ruiz-Guajardo, J. C., A. Otero-Arnaiz, T. TAYlor, G. Stone, C. T. Glenn, N. A. Schnabel, J. T. Miller, S. PReuss and A. SchNABEL (2007): Isolation of polymorphic microsatellite markers in the sub-Saharan tree, Acacia (senegalia) mellifera (Fabaceae: Mimosoideae). Molecular Ecology Notes 7: 1138-1140.

Schnabel, A., A. Otero-Arnaiz, T. C. Glenn, N. A. Schnabel, C. HAGENT and L. Ndong (2005): Isolation and characterization of microsatellite markers in the East African tree, Acacia brevispica (Fabaceae: Mimosoideae). Molecular ecology notes 5: 366-368. 